\title{
Wybrane kierunki i aspekty przemian funkcionalnych terenów przemysłowych we Wrocławiu w latach 1989-2016
}

\section{Selected Directions and Aspects of Functional Changes of Industrial Areas in Wroctaw in 1989-2016}

\begin{abstract}
Streszczenie: Struktura przestrzenna miast w Polsce po 1989 roku uległa istotnym przeobrażeniom. Do terenów miejskich, które znacząco zmieniły swoje oblicze po tym okresie, można zaliczyć tereny przemysłowe, które z uwagi na swoje atrakcyjne położenie w tkance miejskiej i duży rezerwuar powierzchni były wyjątkowo podatne na zaistniałe nowe procesy oraz zjawiska społeczno-gospodarcze. W wyniku tych przemian na jednolite dotąd tereny przemysłowe zaczęły wkraczać podmioty o innej funkcji niż produkcyjna. Dochodziło do sukcesji funkcjonalnej. Celem opracowania jest pokazanie najważniejszych kierunków i aspektów przemian funkcjonalnych terenów przemysłowych we Wrocławiu w latach 1989-2016. Artykuł powstał na bazie analizy danych REGON (1999, 2004, 2009 i 2016) i przeprowadzonych badań terenowych. Proces zmiany funkcji terenów przemysłowych istotnie zmienił większość terenów produkcyjnych miasta, wywołując zmiany morfologiczno-fizjonomiczne, funkcjonalne oraz społeczne. Na dynamikę zmian funkcji tego rodzaju terenów wpływa głównie specyfika ich lokalizacji (bliskość centrum, położenie względem głównych ciągów komunikacyjnych miasta), rodzaj prowadzonej działalności przemysłowej, stan techniczny budynków, kondycja finansowa zakładu przemysłowego i wiele innych czynników. Badany proces ma często charakter nieplanowanych przemian o niekontrolowanej dynamice i formie zmian.
\end{abstract}

\footnotetext{
Abstract: The spatial structure of cities in post-1989 Poland underwent significant transformations. The urban areas that significantly changed their image were industrial areas. Due to their attractive location in the city, they were susceptible to new processes and socio-economic phenomena. As a result of these changes, entities of a function other than production entered the uniform industrial site. The process of functional succession was observed. The aim of the study is to indicate the most important directions and aspects of functional changes of industrial areas in Wroclaw in the years 1989-2016. The article was created on the basis of REGON data analysis (1999, 2004, 2009 and 2016) and field studies. The process of changing the functions of industrial areas has significantly changed most of the city's production areas, causing morphological and physiognomic changes, as well as functional and social changes. The dynamics of changes in the functions of this type of urban areas are mainly influenced by the specificity of their location (proximity to the city centre, location relative to the main transport routes of the city), type of industrial activity, technical condition of buildings, financial condition of the industrial plant and many other factors. The studied process is often an unplanned transformation with uncontrolled change dynamics.
} 
Słowa kluczowe: przemiany funkcjonalne; tereny przemysłowe; Wrocław

Keywords: functional changes; industrial areas; Wrocław

Otrzymano: 31 grudnia 2018

Received: 31 December 2018

Zaakceptowano: 8 lipca 2019

Accepted: 8 July 2019

Sugerowana cytacja / Suggested citation:

Sikorski, D. (2019). Wybrane kierunki i aspekty przemian funkcjonalnych terenów przemysłowych we Wrocławiu w latach 1989-2016. Prace Komisji Geografii Przemysłu Polskiego Towarzystwa Geograficznego, 33(4), 227-240. doi: 10.24917/20801653.334.14

\section{WSTĘP}

Polska w ciągu ostatnich kilkudziesięciu lat istotnie się zmieniła. Transformacja ustrojowa i gospodarcza, która rozpoczęła się w 1989 roku, znacząco wpłynęła na przebieg procesów i zjawisk społeczno-gospodarczych zachodzących w naszym kraju. Przemiany przestrzenne, społeczne, demograficzne i gospodarcze, które nastąpiły w tym okresie, szczególnie widoczne były i są w strukturze przestrzennej miast.

Miasta polskie z szarych, brudnych i często bardzo podobnych do siebie form postsocjalistycznych przeistoczyły się w kolorowe, funkcjonalne i pełne życia, różnorodne organizmy miejskie. A w wyniku pojawienia się nowego, wolnorynkowego modelu funkcjonowania i zarządzania przestrzenią miejską ogromnym przekształceniom uległy jednolite dotąd strefy funkcjonalne miast, powodując często ich rozproszenie oraz atomizację funkcji i powierzchni. Do terenów miejskich, które znacząco zmieniły swoje oblicze po 1989 roku, można bez wątpienia zaliczyć obszary przemysłowe, które z uwagi na swoje atrakcyjne położenie w tkance miejskiej i duży rezerwuar powierzchni były wyjątkowo podatne na zaistniałe nowe procesy oraz zjawiska społeczno-gospodarcze.

Warto zaznaczyć, że historia przeobrażeń terenów przemysłowych w miastach naszego regionu Europy różniła się od historii przemian tego rodzaju obszarów w miastach Europy Zachodniej. Główną przyczyną tych różnic był panujący w krajach Europy Środkowo-Wschodniej (w tym w Polsce) do końca lat osiemdziesiątych XX wieku ustrój socjalistyczny z gospodarką centralnie sterowaną, który skutecznie blokował naturalne mechanizmy przeobrażeń przestrzeni miejskiej, w tym terenów przemysłowych.

Wśród mnogości różnic między gospodarkami wolnorynkowymi a gospodarkami centralnie planowanymi należy podkreślić zjawisko deindustrializacji i deglomeracji przemysłu (Muller, Finka, Lintz, 2005). W krajach Europy Zachodniej proces ten w dużych miastach został zapoczątkowany w latach sześćdziesiątych XX wieku i pogłębił się po kryzysie paliwowym w 1973 roku. W dużych aglomeracjach Europy Zachodniej notowano wówczas wyraźne spadki aktywności przemysłowej, które w konsekwencji doprowadziły do pogłębienia się przekształceń przestrzeni miejskiej (Piech, 1998; Muller, Finka, Lintz, 2005).

Wraz ze zmianami ustrojowymi w krajach Europy Środkowo-Wschodniej, zapoczątkowanymi w Polsce w 1989 roku, przemysł, a w konsekwencji tereny przemysłowe w miastach, znalazł się w głębokim kryzysie. Sztucznie chroniony sektor w realiach wolnorynkowych okazał się mało wydajny. Na początku lat dziewięćdziesiątych XX wieku w większości krajów postkomunistycznych Europy Środkowo-Wschodniej nastąpił upadek przemysłu, zwłaszcza przemysłu ciężkiego, co skutkowało kryzysem 
produkcji i eksportu, spadkiem płac, zanikiem miejsc pracy, słabą opieką społeczną i ochroną związkową (Barski, Zathey, 2018: 20). Szybkie odnowienie zatrudnienia w takich zakładach przemysłowych było niezwykle rzadkie, ponieważ kapitał zagraniczny nie był zainteresowany przejęciem przestarzałych, nierentownych hut, kopalń czy fabryk nawozów. Inwestycje zagraniczne w coś bardziej zaawansowanego niż zwykły montaż zaczęły się pojawiać w krajach postsocjalistycznych dopiero po roku 2000 (Barski, Zathey, 2018: 20, za: Bohle, Greskovits, 2007).

Wprowadzenie zasad wolnego rynku, takich jak renta gruntowa, konkurencja lub swobodny przepływ osób i usług, przyczyniło się do recesji sektora przemysłowego (cierpiącego z powodu niskiej jakości produktów, wysokich kosztów produkcji i złych decyzji lokalizacyjnych). W konsekwencji wiele zakładów przemysłowych po 1989 roku, nie mogąc znaleźć się w nowej rzeczywistości gospodarczej, ogłaszało upadłość lub przechodziło głęboką i bolesną restrukturyzację (Sikorski, 2013). Nieprzystosowanie się do nowych metod i zasad funkcjonowania gospodarki wolnorynkowej zazwyczaj prowadziło do stopniowego lub - w skrajnych przypadkach - natychmiastowego upadku zakładu przemysłowego. Dochodziło do swoistej deindustrializacji terenów przemysłowych w tkance miejskiej - ograniczenia działalności gospodarczej w danym miejscu (Jałowiecki, 1996).

W wyniku naturalnych mechanizmów wolnorynkowych na tereny przemysłowe, nieużytkowane przez zakłady produkcyjne, zaczęły powoli wkraczać nowe podmioty gospodarcze. Reprezentowały one często nowe funkcje, wykorzystując w dużej mierze zastałą zabudowę. Jednolity dotąd teren funkcjonalny (przemysłowy) stawał się dychotomiczny lub wielofunkcyjny. Dochodziło do swoistej fragmentaryzacji danego obszaru, zarówno pod względem morfologicznym (wydzielanie, podział obszaru na mniejsze działki), jak i funkcjonalnym (pojawienie się nieprzemysłowych podmiotów gospodarczych lub powstanie nieużytku poprzemysłowego). Następował tzw. proces sukcesji funkcjonalnej (Sikorski, 2013: 6). Bardzo niewiele terenów przemysłowych Wrocławia zmieniło swoje oblicze w wyniku planowanego procesu rewitalizacji. Zdecydowana większość zaobserwowanych przeobrażeń miała charakter żywiołowy i nieplanowany.

Celem niniejszego opracowania jest przedstawienie wybranych kierunków i aspektów przemian funkcjonalnych zachodzących na terenach przemysłowych Wrocławia w latach 1989-2016. W artykule pokrótce scharakteryzowana została działalność przemysłowa w stolicy Dolnego Śląska, stan i rozmieszczenie terenów przemysłowych w mieście oraz stopień przekształceń funkcjonalnych badanych miejsc. Pokazano, jakie są główne kierunki i następstwa (oblicza) badanego zjawiska dla tego rodzaju terenu miejskiego we Wrocławiu. Ponadto w artykule przedstawiono współczesne trendy w badanym zjawisku.

\section{METODY I ŹRÓDŁA DANYCH}

Artykuł opiera się na wieloletnich badaniach prowadzonych przez autora nad zagadnieniem procesu sukcesji funkcjonalnej na terenach przemysłowych miast województwa dolnośląskiego, w tym szczególnie we Wrocławiu. Proces ten można zdefiniować jako proces zmiany użytkowania ziemi, polegający na stopniowym wypieraniu funkcji przemysłowej z terenów produkcyjnych przez pojawienie się w tych miejscach podmiotów gospodarczych ze sfery pozaprodukcyjnej lub przez powstanie nieużytku poprzemysłowego (Sikorski, 2013). 
Punktem wyjścia do badań była analiza bazy danych REGON dla Wrocławia dla lat: 1999, 2004, 2009 i 2016. Na jej podstawie wyznaczono 257 terenów przemysłowych w mieście, charakteryzujących się zwiększoną koncentracją działalności produkcyjnej. Następnie zebrany materiał faktograficzny został zweryfikowany w terenie. Bezpośrednia inwentaryzacja wyznaczonych terenów przemysłowych pozwoliła na: weryfikację danych, zbadanie procesu sukcesji funkcjonalnej (inwentaryzacja podmiotów o innych funkcjach niż funkcja produkcyjna), określenie stopnia przemian funkcjonalnych konkretnych terenów przemysłowych oraz wyrysowanie poglądowych map obrazujących proces sukcesji funkcjonalnej.

Określając stopień zaawansowania przemian i procesu sukcesji funkcjonalnej na terenach przemysłowych we Wrocławiu, zaproponowano klasyfikację opartą na koncepcji cyklu przemian morfologicznych działki miejskiej M.R.G. Conzena (1960). Opracował on ramy pojęciowe dla morfologii miast, zaś jego osiągnięcia okazały się kluczowe dla zrozumienia złożoności krajobrazu miejskiego. Wprowadził m.in. jego trójpodział na:

1. plan miasta (obejmujący ulice, działki i budynki),

2. typy zabudowy,

3. formy użytkowania terenów miejskich.

Cozen ustalił również prawidła metodologiczne wykorzystania planu miasta jako podstawy źródłowej historycznej analizy morfologicznej (Deptuła, 2016: 27, za: Conzen, 1960). Jednak największe znaczenie dla rozwoju badań z zakresu urbomorfologii miały rozwinięte przez niego koncepcje wyjaśniające proces przeobrażeń struktur przestrzennych miast, spośród których wymienić należy koncepcje burgage cycle (cyklu przemian morfologicznych działki miejskiej) oraz fringe belts (pasów/pierścieni obrzeży miejskich) (Deptuła, 2016: 27, za: Koter, Kulesza, 2007; 2008). Warto wspomnieć, że pierwszym naukowcem w Polsce, który zastosował koncepcję conzenowską do badań przemian miejskich i stworzył na tej podstawie podwaliny do dalszych badań, był M. Koter (1969; 1974).

Na podstawie wymienionych rozważań i własnych przemyśleń wydzielono następujące stopnie zaawansowania przemian oraz procesu sukcesji funkcjonalnej na terenach przemysłowych:

a) tereny o stabilnej funkcji przemysłowej - istnieją w danym mieście ponad 20 lat i występują na nich wyłącznie podmioty przemysłowe;

b) tereny $w$ fazie inicjacji:

- wstępnej - to tereny przemysłowe, na których po 1989 roku pojawiło się maksymalnie do trzech nowych nieprzemysłowych podmiotów gospodarczych, ściśle związanych z zakładami tam występującymi (np. sklep firmowy lub centrum logistyczne danego zakładu przemysłowego);

- właściwej - to tereny przemysłowe, na których po 1989 roku pojawiło się do trzech nowych nieprzemysłowych podmiotów gospodarczych, które nie były w ścisłej zależności (nie były w żaden sposób powiązane) z występującymi tam podmiotami przemysłowymi;

c) tereny w fazie wypełnienia - to tereny przemysłowe, na których po 1989 roku pojawiły się więcej niż trzy nowe pozaprodukcyjne podmioty gospodarcze, zajmują one więcej niż 50\% powierzchni danego obszaru;

d) tereny w fazie kulminacji - to tereny przemysłowe, na których po 1989 roku pojawiły się więcej niż trzy nowe nieprzemysłowe podmioty gospodarcze, zajmują one co najmniej $90 \%$ powierzchni danego obszaru. 


\section{PRZEMYSŁ I TERENY PRZEMYSŁOWE WROCŁAWIA}

Wrocław jest miastem o długiej tradycji produkcyjnej, działalność rzemieślnicza i produkcyjna w manufakturach legły u podstaw rozwoju jego przemysłu (Kulak, 2001). Mimo upływu lat stolica Dolnego Śląska nadal jest wielkim ośrodkiem przemysłowym, z wyraźną dominacją przemysłu metalowo-maszynowego, skupiającego w momencie prosperity ponad 50\% z ogółu zatrudnionych w przemyśle. Rozwinięty był tu i jest nadal przemysł metalowy, maszynowy, przemysł środków transportu, urządzeń precyzyjnych, elektrotechnicznych i elektronicznych (Sikorski, 2013: 99, za: Kwiatek, Lijewski, 1998).

Zakłady przemysłowe lokowane były głównie wzdłuż szlaków komunikacyjnych i transportowych, zarówno wodnych, jak i kolejowych. Takie rozmieszczenie lokalizacji działalności produkcyjnej we Wrocławiu wynikało przede wszystkim z zależności zakładów przemysłowych od dostaw surowców i półfabrykatów przewożonych środkami transportu kolejowego i wodnego lub z powstających więzi kooperacyjnych, tzw. korzyści natury techniczno-technologicznej, jakie mogły wywiązać się między zakładami (rycina 1) (Slenczek, 1996).

W latach 1989-2016 we Wrocławiu liczba pracujących w przemyśle spadła z 80200 do 39185 osób, czyli o ponad 50\%. Przemysł zatrudniał tylko 14,6\% aktywnych zawodowo wrocławian (Wrocław $w$ liczbach, 2017). Liczba podmiotów przemysłowych w latach 1999-2016 spadła z 8573 do 7861, co stanowiło 6,5\% wszystkich podmiotów gospodarczych miasta (REGON 1999 i 2016).

Rycina 1. Strefy przemysłowe we Wrocławiu

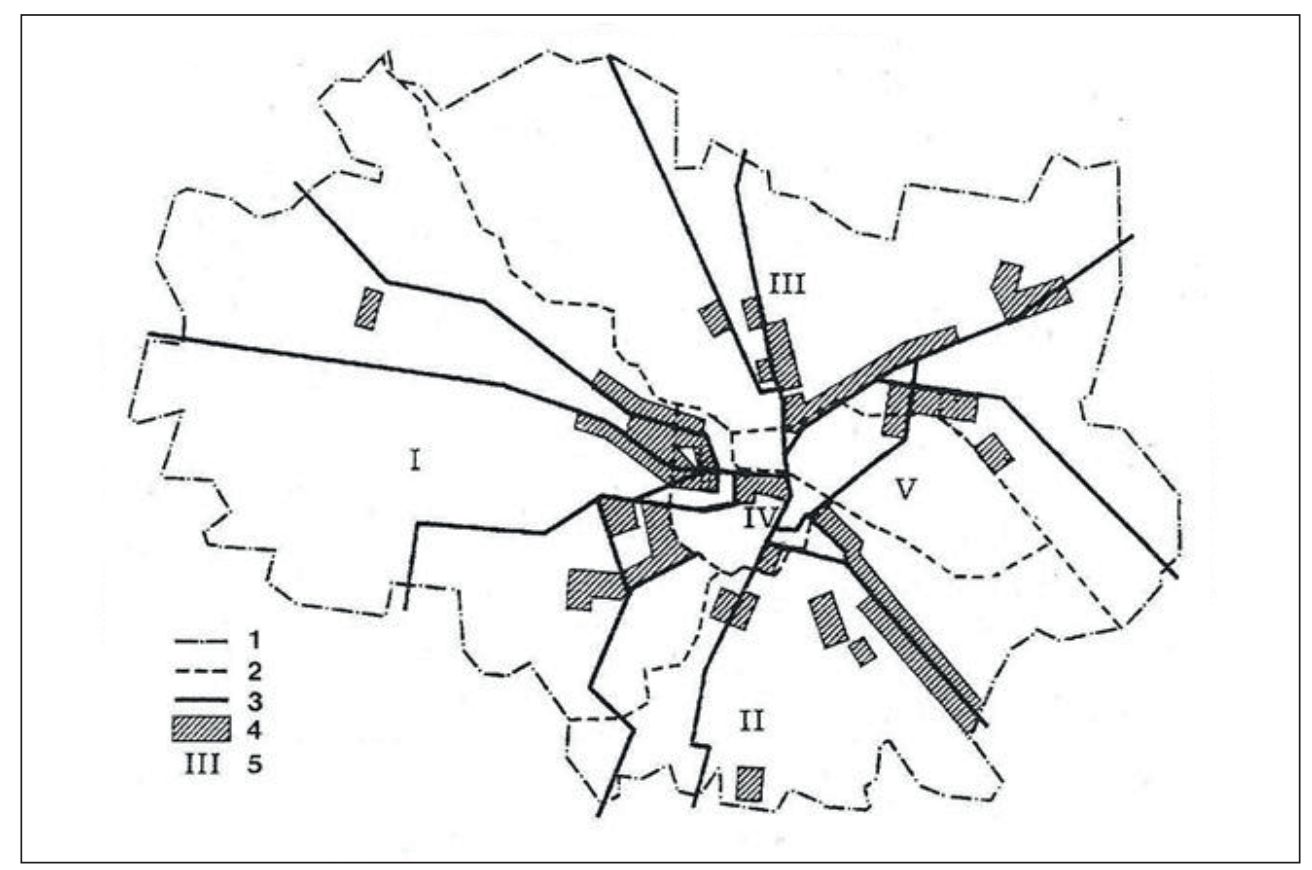

1 - granica miasta, 2 - granice dzielnic, 3 - ciągi komunikacyjne, 4 - strefy przemysłowe, 5 - dzielnice miasta Źródło: Slenczek (1996: 87) 
Na terenie Wrocławia można wyróżnić aż 257 większych obszarów przemysłowych, które zajmują powierzchnię łącznie blisko 1900 ha (6,4\% powierzchni miasta). Zdecydowana większość tych terenów powstała przed 1989 rokiem.

W analizowanym okresie w mieście było zlokalizowanych ponad 50 ważnych zakładów przemysłowych wymienionych w Encyklopedii Wrocławia (Harasimowicz, 2006) jako podmioty o zasięgu regionalnym lub ogólnokrajowym. Z nieistniejących już zakładów były to m.in.:

- Cukrownia „Wrocław” SA: zlokalizowana przy al. Poprzecznej 37, która powstała w 1881 roku. Jeszcze w 1999 roku była dużym zakładem pracy, zatrudniającym kilkaset osób, a w 2008 roku została zamknięta, w 2010 roku zaś wyburzona. Obecnie teren cukrowni jest przykładem nieużytku poprzemysłowego.

- Młyn Sułkowice: zlokalizowany przy al. Poprzecznej 33-35, powstał w 1890 roku. Od blisko 10 lat nie funkcjonuje. Na terenie młyna zlokalizowanych jest obecnie 13 nieprzemysłowych podmiotów gospodarczych (głównie handlowych), a co niedzielę na placu wokół zakładu odbywa się targ staroci. Od kilku lat planuje się przeprowadzić proces rewitalizacji mający doprowadzić do powstania Centrum Wielofunkcyjnego „Stary Młyn”; z powodu braku funduszy koncepcja ta jest na razie w fazie projektowej.

- Browary Dolnośląskie „Piast” SA: zlokalizowane przy ul. Jedności Narodowej 204-210, powstały w latach 1892-1894, produkowały piwo do 2004 roku. Początkowo miało tu powstać centrum usługowo-handlowe dla północnego Wrocławia, z przerobionymi dawnymi budowlami na nowoczesne lofty. W wyniku trudnej sytuacji na rynku nieruchomości w 2008 roku inwestor wycofał się ze swoich planów. Ostatecznie w 2016 roku teren zakładu kupił wrocławski deweloper Archicom, który zaczął realizację kompleksowego założenia urbanistycznego, obejmującego mieszkania, lofty, sklepy i biura o nazwie Browary Wrocławskie oraz powstanie na sąsiedniej działce osiedla mieszkaniowego - osiedle Jedności.

- Wrocławskie Zakłady Materiałów Ogniotrwałych SA: zlokalizowane przy ul. Trzmielowickiej 16-20, powstały w 1889 roku. Jeszcze w 1999 roku prowadziły działalność, a następnie przez kolejne 10 lat popadały w ruinę, aż zostały wyburzone na przełomie lat 2009/2010. Dziś to nieużytek poprzemysłowy.

- Rzeźnia miejska: zlokalizowana przy ul. Legnickiej 58, powstała w latach 18831896. Mimo kilkudziesięciu lat funkcjonowania zakład ten nie sprostał wymogom nowej rzeczywistości ekonomicznej po 1989 roku. Ostatecznie opuszczone i zrujnowane budynki pofabryczne o dużej wartości zabytkowej wyburzono w 1999 roku mimo licznych protestów mieszkańców oraz przedstawicieli świata nauki i sztuki. Tereny te do 2007 roku stanowiły przykład nieużytku poprzemysłowego. W 2007 roku działkę zakupił prywatny inwestor, który postawił tam centrum handlowe „Magnolia Park” (Sikorski, 2013).

Obecnie w mieście zostały już tylko 34 duże zakłady przemysłowe, zatrudniające ponad 250 pracowników (REGON 2016). Wśród nich są m.in. następujące podmioty:

- HS Wrocław sp. z o.o.: zlokalizowana przy ul. Bierutowskiej 65-67, powstała w 1946 roku jako PZL-Hydral. Przez wiele lat zakład ten zatrudniał ponad 1000 pracowników, obecnie - ok. 900 osób.

- Delaval Operations sp. z o.o.: zlokalizowana przy ul. Robotniczej 72, powstała w 1875 roku jako Fabryka Maszyn Rolniczych „Archimedes”. Obecnie zakład zatrudnia ponad 250 pracowników. Na tych terenach znajduje się także siedem 
innych przemysłowych i 41 nieprzemysłowych podmiotów gospodarczych (głównie handlowych).

- Bombardier Transportation Polska sp. z o.o.: zlokalizowana przy ul. Robotniczej 12, powstała w 1839 roku jako Linke-Hofmann-Werke AG, a od 1945 roku jako Fabryka Wagonów „Pafawag”. Zakład obecnie zatrudnia ok. 800 osób. Ponadto znajduje się tam też 30 podmiotów gospodarczych, w tym sześć przemysłowych i 24 nieprzemysłowe.

- Volvo Polska sp. z o.o.: zlokalizowana przy ul. Mydlanej 2; obecnie zatrudnia ponad 1000 pracowników. Na terenie zakładu działają dwa związki zawodowe (Sikorski, 2013).

Współcześnie zdecydowana większość nowo powstających dużych zakładów przemysłowych wybiera na swoją lokalizację raczej tereny leżące w strefie podmiejskiej Wrocławia (np. Bielany Wrocławskie, gmina Długołęka, gmina Kobierzyce) niż w samym mieście. Związane jest to m.in. z polityką deglomeracji działalności przemysłowej z dużych miast, mechanizmem renty gruntowej i dostępnością komunikacyjną.

Na malejące znaczenie działalności przemysłowej w mieście, zarówno pod względem struktury zatrudnienia mieszkańców, jak i samej liczby podmiotów przemysłowych miało wpływ wiele czynników. Zmiany zachodzące w systemie produkcji oddziałują na przekształcanie jej przestrzennej organizacji. Dokonuje się ono pod wpływem zmian w społecznym podziale pracy, zmian korzyści zewnętrznych, większej elastyczności rynku pracy, silniejszego powiązania przemysłu z lokalnymi warunkami społeczno-ekonomicznymi. W efekcie dochodzi do zmian lokalizacyjnych podstaw współczesnej gospodarki i tworzenia nowych skupień przemysłu, pojawiają się też jego tendencje lokalizacyjne. Nowe przestrzenie przemysłowe są wieloośrodkowe i mniej skoncentrowane, a rozwój przemysłu jest silnie zakorzeniony w lokalnych warunkach społeczno-gospodarczych (Brezdeń, Szmytkie, 2017: 56, za: Scott, 1985; 1988).

W dobie postindustrialnej narastające koszty funkcjonowania miast, postęp naukowo-techniczny, wzrost poziomu wykształcenia ludności i liczne bariery ekologiczne przyczyniają się do decentralizacji działalności gospodarczej. Jedną z konsekwencji tego zjawiska jest zwiększenie atrakcyjności lokalizacyjnej strefy podmiejskiej (Brezdeń, Szmytkie, 2017: 57). W efekcie znaczna część działalności przemysłowej Wrocławia przeniosła się do jej strefy podmiejskiej.

\section{KIERUNKI I OBLICZA PRZEOBRAŻEŃ TERENÓW PRZEMYSŁOWYCH MIASTA}

Przemiany terenów przemysłowych Wrocławia miały różnorodną genezę. Część z nich straciła swą jednolitą funkcję i charakter produkcyjny w wyniku zaistnienia mechanizmu renty gruntowej, upadku (bankructwa) w danym miejscu działalności przemysłowej lub świadomej polityki deglomeracji działalności sektora II gospodarki narodowej do strefy podmiejskiej.

Na podstawie wieloletnich obserwacji przeobrażeń terenów przemysłowych i samego procesu sukcesji funkcjonalnej we Wrocławiu można zauważyć, że zaistniałe zmiany zostały zapoczątkowane na większą skalę po 2000 roku. Owe procesy przyniosły głębokie i niekontrolowane przeobrażenia w strukturze przestrzennej badanych miejsc. W konsekwencji na terenach przemysłowych Wrocławia doszło do zmian o charakterze: 
a) morfologiczno-fizjonomicznym - polegały one na zmianie przebiegu granic i samego wyglądu działek przemysłowych, które bardzo często przez kilkadziesiąt lat niemal się nie zmieniały; zaobserwowano proces stopniowego wycofywania się działalności produkcyjnej od frontu działki w jej głąb na rzecz nieprzemysłowych podmiotów gospodarczych (głównie sklepów lub biur) - prawidłowość tę można było dostrzec szczególnie na atrakcyjnie położonych działkach wzdłuż głównych arterii komunikacyjnych miasta (rycina 2); także bardzo mocno zmienił się wygląd terenów przemysłowych - wiele z nich to obecnie miejsca, które z daleka przyciągają wzrok różnorodnymi i kolorowymi banerami reklamowymi;

Rycina 2. Schemat procesu zajmowania frontu działek przemysłowych przez nowe funkcje

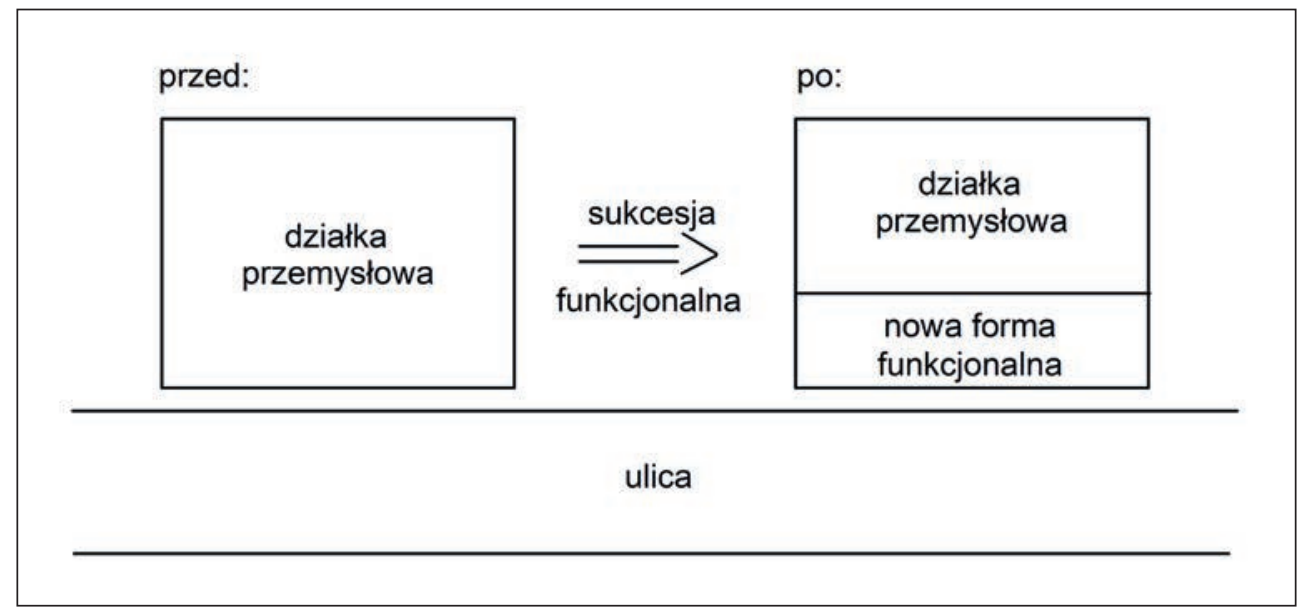

Źródło: opracowanie własne

b) funkcjonalnym - na do tej pory jednolite tereny przemysłowe zaczęły wkraczać nowe podmioty gospodarcze, niezwiązane $\mathrm{z}$ działalnością produkcyjną, powodując, że tereny te stawały się wielofunkcyjne, z wszystkimi tego następstwami (rycina 3);

c) społecznym - zmiany te przyczyniły się do bezpośredniego spadku liczby pracujących w mieście i powstania bezrobocia oraz wymusiły konieczność przekwalifikowania się byłych pracowników sektora produkcyjnego lub podjęcia pracy w strefie podmiejskiej Wrocławia; bardzo często nowo powstałe podmioty gospodarcze, wkraczające na tereny przemysłowe zapewniały mniej miejsc pracy niż funkcjonujące tam wcześniej podmioty przemysłowe (Sikorski, 2013).

\section{PROCES SUKCESJI FUNKCJONALNEJ I STOPIEŃ PRZEOBRAŻEŃ TERENÓW PRZEMYSŁOWYCH WROCŁAWIA}

Proces sukcesji funkcjonalnej na terenach przemysłowych Wrocławia wystąpił jeszcze przed 1989 rokiem. Na progu zmian ustrojowych w całym kraju - 42,92 ha terenów przemysłowych miasta zajętych było przez nowe funkcje (tabela 1). Największa koncentracja nowych form funkcjonalnych na badanych terenach wystąpiła głównie w centralnej części miasta oraz wzdłuż linii kolejowej w kierunku Oławy (Sikorski, 2013). 
Rycina 3. Mapa poglądowa przemian funkcjonalnych terenów przemysłowych między ulicą Hubską a Krakowską we Wrocławiu według stanu na 2016 rok

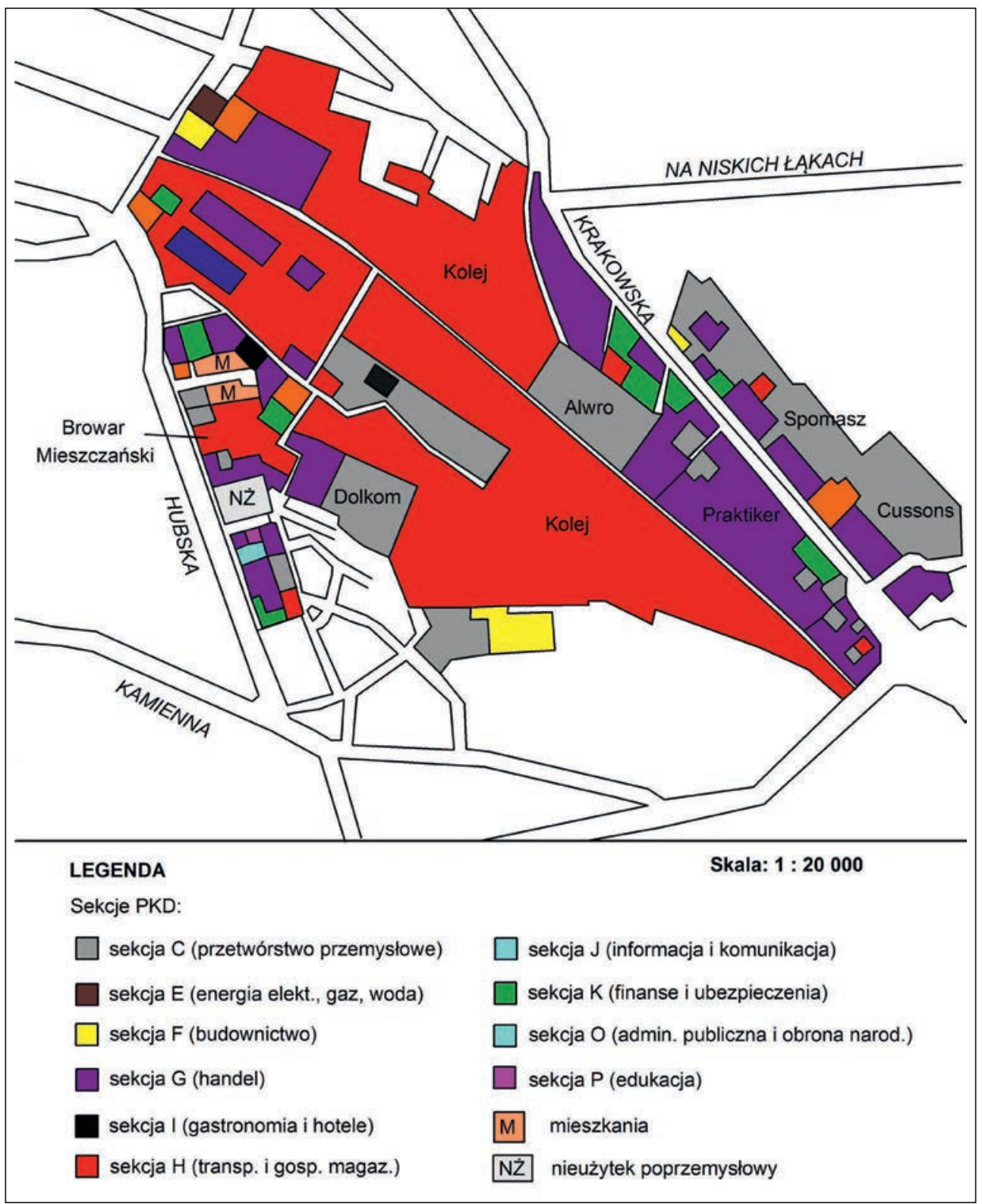

Źródło: opracowanie własne na podstawie Sikorski (2009), badań terenowych i bazy danych REGON (2016)

Na skutek przemian funkcjonalnych na badanych terenach powstały łącznie 6392 nowe podmioty gospodarcze, 24 miejsca zajęte były pod budownictwo mieszkaniowe, a tylko cztery były nieużytkami poprzemysłowymi. Łącznie proces sukcesji funkcjonalnej objął 1241,13 ha, co stanowiło blisko 65,3\% pierwotnej powierzchni terenów przemysłowych w 1989 roku. 
Pod względem dynamiki przyrostu liczby nowych podmiotów o innej funkcji niż produkcyjna najwięcej nowych form funkcjonalnych pojawiło się w ostatnich latach (w latach 2010-2016 wzrost o 3655 form). Patrząc jednak na przyrost powierzchni zajmowanej przez nowe funkcje na terenach przemysłowych Wrocławia, można zauważyć, że nowe podmioty gospodarcze z roku na rok charakteryzowały się mniejszą dynamiką przyrostu powierzchni. Oznaczać to może, że proces sukcesji funkcjonalnej w początkowych latach występowania miał charakter powierzchniowy, aby następnie stać się zjawiskiem ilościowym. Związane mogło to być z tym, że początkowo rezerwuar powierzchni zwalnianej przez działalność przemysłową był znaczny, a nowe podmioty pojawiające się $\mathrm{w}$ tym miejscu zajmowały większą powierzchnię, niż wynikało to z ich działalności i potrzeb. Gdy jednak cena gruntów we Wrocławiu wraz z upływem lat zaczęła wzrastać, na terenach przemysłowych objętych sukcesją funkcjonalną dochodziło do koncentracji podmiotów i maksymalnego wykorzystania powierzchni.

Tabela 1. Nowe formy funkcjonalne na terenach przemysłowych we Wrocławiu według okresu powstania

\begin{tabular}{|l|c|c|c|c|}
\hline \multirow{2}{*}{ Rok } & \multicolumn{2}{|c|}{ Nowe formy } & \multicolumn{2}{c|}{ Powierzchnia nowych form } \\
\cline { 2 - 5 } & (liczba)* & $(\mathrm{w} \%)^{*}$ & $(\mathrm{w}$ ha) & $(\mathrm{w} \%)^{*}$ \\
\hline do 1989 & 78 & 1,2 & 42,92 & 3,5 \\
\hline $1990-1994$ & 682 & 10,7 & 306,11 & 24,7 \\
\hline $1995-1999$ & 1280 & 20,0 & 695,64 & 56,0 \\
\hline $2000-2004$ & 1954 & 30,5 & 866,45 & 69,8 \\
\hline $2005-2009$ & 2765 & 43,2 & 979,86 & 78,9 \\
\hline $2010-2016$ & 6420 & 100,0 & 1241,13 & 100,0 \\
\hline
\end{tabular}

* wartości kumulowane

Źródło: opracowanie własne na podstawie Sikorski (2013), badań terenowych i bazy danych REGON

Najwięcej nowych form funkcjonalnych, które powstały na terenach przemysłowych Wrocławia po 1989 roku, stanowiły handlowe podmioty gospodarcze. Sekcja G pod koniec 2016 roku na terenach produkcyjnych miasta reprezentowana była przez 1603 podmioty, które zajmowały łącznie powierzchnię 609,39 ha. Kolejną formą funkcjonalną, która odgrywała znaczną rolę w strukturze nowych firm, były podmioty z sekcji M (1020 podmiotów; powierzchnia 26,06 ha). Tak duża liczba podmiotów związanych z działalnością profesjonalną, naukową i techniczną na tego typu terenach może mieć związek z rolą Wrocławia jako ośrodka akademickiego, miasta, które stawia na rozwój zaawansowanych technologii. Duże znaczenie w badanym procesie miały także podmioty reprezentujące budownictwo (sekcję F), co wydaje się naturalną konsekwencją adaptacji terenów przemysłowych do funkcjonowania tego rodzaju firm (695 podmiotów; 70,74 ha) (tabela 2).

W ostatnich latach zauważalny jest wzrost presji deweloperów na przekształcanie terenów przemysłowych na osiedla mieszkaniowe. W sytuacji, kiedy z roku na rok coraz bardziej brakowało przestrzeni dla funkcji mieszkaniowej miasta, tereny przemysłowe, często zlokalizowane w centralnej części Wrocławia, okazały się doskonałym rezerwuarem powierzchni dla tej funkcji. Przykładem wywierania wspomnianego nacisku są powstające osiedla mieszkaniowe na terenie lub w najbliższym sąsiedztwie cukrowni Klecina i Portu Miejskiego we Wrocławiu. 
Tabela 2. Struktura sukcesji funkcjonalnej na terenach przemysłowych według malejącego udziału podmiotów we Wrocławiu w 2016 roku

\begin{tabular}{|l|c|c|c|c|}
\hline \multirow{2}{*}{ Sekcja } & \multicolumn{2}{c|}{ Podmioty } & \multicolumn{2}{c|}{ Powierzchnia } \\
\cline { 2 - 5 } & Liczba & Udział (w \%) & Suma (w ha) & Udział (w \%) \\
\hline G - handel & 1603 & 25,0 & 609,39 & 49,1 \\
\hline $\begin{array}{l}\text { M - działalność profesjonalna, naukowa } \\
\text { i techniczna }\end{array}$ & 1020 & 15,9 & 26,06 & 2,1 \\
\hline F - budownictwo & 695 & 10,8 & 70,74 & 5,7 \\
\hline L - obsługa nieruchomości & 486 & 7,6 & 3,72 & 0,3 \\
\hline J - informacja i komunikacja & 396 & 6,2 & 12,41 & 1,0 \\
\hline S - pozostała działalność usługowa & 393 & 6,1 & 11,17 & 0,9 \\
\hline K - finanse i ubezpieczenia & 347 & 5,4 & 4,96 & 0,4 \\
\hline H - transport i gospodarka magazynowa & 286 & 4,5 & 311,52 & 25,1 \\
\hline Q - opieka zdrowotna i pomoc społeczna & 279 & 4,3 & 7,45 & 0,6 \\
\hline N - usługi administracyjne i wspierające & 268 & 4,2 & 3,72 & 0,3 \\
\hline P - edukacja & 189 & 2,9 & 9,93 & 0,8 \\
\hline I - gastronomia i hotele & 175 & 2,7 & 6,21 & 0,5 \\
\hline A - rolnictwo & 145 & 2,3 & 1,24 & 0,1 \\
\hline R - kultura, rozrywka i rekreacja & 107 & 1,7 & 9,93 & 0,8 \\
\hline Mieszkania & 24 & 0,4 & 124,11 & 10,0 \\
\hline Nieużytki poprzemysłowe & 420 & 0,1 & 14,89 & 1,2 \\
\hline O - administracja publiczna i obrona & 3 & 0,0 & 13,65 & 1,1 \\
\hline narodowa & 200,0 & 1241,13 & 100,0 \\
\hline
\end{tabular}

Źródło: opracowanie własne na podstawie Sikorski (2013), badań terenowych i bazy danych REGON

Na podstawie przeprowadzonych badań wyznaczono fazy (etapy) sukcesji funkcjonalnej poszczególnych terenów przemysłowych Wrocławia (tabela 3). Można stwierdzić, że zdecydowana większość tego rodzaju miejsc uległa przeobrażeniom funkcjonalnym. Pod względem liczbowym aż 96 terenów przemysłowych (37,3\%) znajduje się w fazie głębokich przeobrażeń, a na kolejnych $70(27,3 \%)$ proces ten już wystąpił z większym lub mniejszym natężeniem. Tylko 91 (35,4\%) terenów przemysłowych istniejących we Wrocławiu od 1989 roku zachowało swą pierwotną monofunkcję produkcyjną.

Tabela 3. Fazy (etapy) sukcesji funkcjonalnej na terenach przemysłowych we Wrocławiu w 2016 roku

\begin{tabular}{|l|r|r|r|r|}
\hline \multicolumn{1}{|c|}{ Faza } & $\begin{array}{c}\text { Tereny } \\
\text { (liczba) }\end{array}$ & $\begin{array}{c}\text { Powierzchnia } \\
\text { (w ha) }\end{array}$ & $\begin{array}{c}\text { Tereny } \\
\text { (w \%) }\end{array}$ & $\begin{array}{c}\text { Powierzchnia } \\
(\mathrm{w} \%)\end{array}$ \\
\hline Tereny o stabilnej funkcji przemysłowej & 91 & 341,11 & 35,4 & 18,1 \\
\hline Inicjacja wstępna & 1 & 0,66 & 0,4 & 0,0 \\
\hline Inicjacja właściwa & 2 & 21,18 & 0,8 & 1,1 \\
\hline Wypełnienie & 67 & 1089,25 & 26,1 & 57,9 \\
\hline Kulminacja & 96 & 430,07 & 37,3 & 22,9 \\
\hline Ogółem & 257 & 1882,27 & 100,0 & 100,0 \\
\hline
\end{tabular}

Źródło: opracowanie własne na podstawie Sikorski (2013), badań terenowych i bazy danych REGON 


\section{PoDSUMOWANIE}

Problematyka badawcza dotycząca terenów przemysłowych jest mocno obecna w dyskursie naukowym. Jednak zdaniem J. Kotlickiej (2008), S. Liszewskiego (1994) i M. Piech (2004) dotychczas w bogatej literaturze geograficznej, dotyczącej struktury przestrzennej i przemysłu miast, powstało niewiele kompleksowych prac poświęconych przeobrażeniom terenów przemysłowych (Sikorski, 2013: 11). Tereny te pojawiały się w literaturze zazwyczaj jako jeden z elementów struktury przestrzennej miasta i były traktowane w sposób kompleksowy wraz z pozostałymi użytkami (Piech, 2004). Jeśli jakaś praca naukowa odnosiła się do przemian terenów przemysłowych i ich aspektu przemian funkcjonalnych, to były to zazwyczaj prace poświęcone studium przypadku rewitalizacji konkretnej działki lub zakładu przemysłowego. Dlatego warto się zastanowić, w jaki sposób przemiany funkcjonalne zachodzące na terenach przemysłowych je przeobrażają.

Przez dokonującą się transformację gospodarczą następuje dekapitalizacja i degradacja wielu terenów poprzemysłowych w zabudowie miejskiej. W wyniku tych procesów narastają negatywne zjawiska społeczne - duże bezrobocie, przestępczość oraz ubóstwo (Miśkowiec, 2016: 201, za: Lorens, Martyniuk-Pęczek, 2009). Jednym z podstawowych narzędzi wykorzystywanych przy procesach naprawczych w tych miejscach jest rewitalizacja. Jej głównym celem jest wyprowadzenie ze stanu kryzysowego obszarów zdegradowanych w sposób kompleksowy, przez zintegrowane działania na rzecz lokalnej społeczności, przestrzeni i gospodarki. Proces rewitalizacji w kontekście przestrzeni miejskiej ma ponownie ożywić teren po degradacji, podnosząc jakość życia mieszkańców oraz jakość przestrzeni publicznej (Miśkowiec, 2016: 201, za: Kaczmarek, 2004).

Na badanych terenach przemysłowych Wrocławia po 1989 roku proces rewitalizacji, rozumiany jako proces wprowadzania planowych zmian mających przywrócić zdegradowane obszary przemysłowe do ponownego ich wykorzystania w przestrzeni publicznej, praktycznie nie występuje. Zachodzące zmiany funkcjonalne, ich tempo i dynamika miały i mają charakter nieplanowany. W efekcie ich następstwa i skutki (morfologiczno-fizjonomiczne, funkcjonalne i społeczne) miały często o wiele bardziej negatywny charakter niż analogiczne przemiany zachodzące na terenach produkcyjnych miast Europy Zachodniej.

Jak pokazano, proces sukcesji funkcjonalnej na terenach przemysłowych Wrocławia został zapoczątkowany już przed 1989 rokiem, ale na większą skalę zaczął się on po tej dacie, jeśli chodzi o wymiar powierzchniowy (do 1999 roku 56\% powierzchni tych obszarów pełniło już inną funkcję), a po 2000 roku, jeśli chodzi o jego aspekt ilościowy (w latach 2010-2016 przybyło 3655 nowych form funkcjonalnych na terenach produkcyjnych miasta, to $56,9 \%$ ogółu). Taka struktura badanego zjawiska związana jest prawdopodobnie ze stopniowym wzrostem znaczenia mechanizmu renty gruntowej w kreowaniu struktury przestrzennej miasta. Mechanizm ten przyczynił się do wzrostu cen gruntu oraz wykorzystania w sposób optymalny przez różne działalności gospodarcze każdej możliwej dostępnej powierzchni w mieście.

Obecnie stopień przeobrażeń funkcjonalnych terenów przemysłowych jest znaczny. Spośród 257 wyznaczonych do badań obszarów aż 166 (64,6\%) w jakimś stopniu uległo przemianom funkcjonalnym, a tylko 91 (35,4\%) terenów z 1989 roku nadal zachowało niezmienioną pierwotną funkcję produkcyjną. Pod względem powierzchniowym 
badane zjawisko charakteryzuje się jeszcze większymi przemianami. Aż 1241,13 ha $(81,9 \%)$ powierzchni terenów przemysłowych z 1989 roku obecnie zajęte jest przez nowe formy funkcjonalne, a tylko 341,11 (18,1\%) utrzymało swoją formę produkcyjną. Potwierdza to wspomniany wcześniej głód ziemi występujący we Wrocławiu.

Przemiany przestrzenne i funkcjonalne terenów przemysłowych Wrocławia, mające swoje odzwierciedlenie w procesie sukcesji funkcjonalnej, będą nadal występować w przestrzeni stolicy Dolnego Śląska. I choć może ich tempo nie będzie już tak duże jak po 1989 roku, to nadal w istotny sposób będą modyfikować strukturę przestrzenną i funkcjonalną miasta.

\section{Literatura \\ References}

Barski, J., Zathey, M. (2018). Industrial heritage and post-industrial situation in the post-transformation era in Lower Silesia (Poland). GeoSpace: Industrial Culture in Urban and Regional Development 12(1), 17-25. Ústí nad Labem: Jan Evangelista Purkyně University.

Brezdeń, P., Szmytkie, R. (2017). Procesy koncentracji działalności przemysłowej w strefie podmiejskiej na przykładzie Dolnego Śląska. Prace Komisji Geografii Przemysłu Polskiego Towarzystwa Geograficznego, 31(2), 56-74.

Bohle, D., Greskovits, B. (2007). Neoliberalism, embedded neoliberalism and neocorporatism. Towards transnational capitalism in Central-Eastern Europe. West European Politics, 30(3), 443-466.

Conzen, M.R.G. (1960). The plan analysis of an English city centre. Lund Studies in Geography, seria $B, 24,383-414$.

Deptuła, M. (2016) Tradycyjne szkoły urbomorfologii a nowe podejścia do analizy miejskich form przestrzennych. Acta Universitatis Lodziensis Folia Geographica Socio-Oeconomica, 25, 25-38.

Harasimowicz, J. (red.) (2006). Encyklopedia Wrocławia. Wrocław: Wydawnictwo Dolnośląskie. Jałowiecki, B. (1996). Społeczne wytwarzanie przestrzeni w okresie transformacji ustrojowej. Biuletyn Komitetu Przestrzennego Zagospodarowania Kraju Polskiej Akademii Nauk, 175, 21-50.

Kaczmarek, S. (2004). Tereny poprzemysłowe w miastach - problem czy wyzwanie? W: J. Słodczyk (red.). Przemiany struktury przestrzennej miast $w$ sferze funkcjonalnej i społecznej. Opole: Wydawnictwo Uniwersytetu Opolskiego, 155-165.

Koter, M. (1969). Geneza układu przestrzennego Łodzi przemysłowej. Prace Geograficzne Instytutu Geografii Polskiej Akademii Nauk, 79.

Koter, M. (1974), Fizjonomia, morfologia i morfogeneza miasta. Przegląd rozwoju oraz próba uściślenia pojęć. Zeszyty Naukowe Uniwersytetu Łódzkiego. Nauki Matematyczno-Przyrodnicze, II(55), 3-16.

Koter, M., Kulesza, M. (2007). Morfologia miast - stan i tendencje rozwoju. W: I. Jażdżewska (red.). Polska geografia osadnictwa. Dotychczasowy dorobek. Program badań. XX Konwersatorium wiedzy o mieście. Łódź: Katedra Geografii Miast i Turyzmu Uniwersytetu Łódzkiego, 303-314.

Koter, M., Kulesza, M. (2008). Zastosowanie metod conzenowskich w polskich badaniach morfologii miast. W: M. Kulesza (red.). Czas i przestrzeń w naukach geograficznych. Wybrane problemy geografii historycznej. Łódź: Uniwersytet Łódzki, 257-272.

Kotlicka, J. (2008). Przemiany morfologiczne terenów przemysłowych Łodzi. Łódź: Łódzkie Towarzystwo Naukowe.

Kulak, T. (2001). Historia Wrocławia. Od twierdzy fryderycjańskiej do twierdzy hitlerowskiej. Wrocław: Wydawnictwo Dolnośląskie.

Kwiatek, J., Lijewski, T. (1998). Leksykon miast polskich, Warszawa: Wydawnictwo Muza.

Liszewski, S. (1994). Studia nad strukturami przestrzennymi miast. W: S. Liszewski (red.). Geografia osadnictwa i ludności w niepodległej Polsce. Tom II: Kierunki badań naukowych. Łódź: Polskie Towarzystwo Geograficzne, 181-199. 
Lorens, P., Martyniuk-Pęczek, J. (red.) (2009). Wybrane zagadnienia rewitalizacji miast. Seria Miasto-Metropolia-Region. Gdańsk: Wydawnictwo Urbanista.

Miśkowiec, M. (2016). Przemiany terenów poprzemysłowych w miejscach dziedzictwa przemysłu włókienniczego na przykładzie Manchesteru, Lyonu i Łodzi. Prace Komisji Geografii Przemysłu Polskiego Towarzystwa Geograficznego, 30(3), 199-212.

Muller, B., Finka, M., Lintz, G. (red.). (2005). Rise and decline of industry in Central and Eastern Europe. A comparative study of cities and regions in eleven countries. Heidelberg: Springer.

Piech, M. (1998). Przemiany przestrzenne i funkcjonalne terenów przemysłowych w Łodzi w latach 1988-1996. W: J. Kaczmarek (red.). Zróżnicowanie przestrzenne struktur społecznych w dużych miastach. Łódź: Wydawnictwo Uniwersytetu Łódzkiego, 117-122.

Piech, M. (2004). Przemiany funkcjonalne terenów przemysłowych w latach 1988-1996 (w granicach kolei obwodowej). Łódź: Łódzkie Towarzystwo Naukowe.

Scott, A.J. (1985). Location processes, urbanization and territorial development. Environment and Planning A, 3, 479-501.

Scott, A.J. (1988). New industrial space. London: Pion.

Sikorski, D. (2009). Wpływ przeobrażeń terenów przemysłowych na fizjonomię i morfologię przestrzeni miejskiej na przykładzie Wrocławia. Problemy Ekologii Krajobrazu, 24, 189-198. Poznań: Uniwersytet Adama Mickiewicza.

Sikorski, D. (2013). Proces sukcesji funkcjonalnej na terenach przemysłowych i poprzemysłowych $w$ miastach województwa dolnośląskiego. Studium przypadków. Wałbrzych: Państwowa Wyższa Szkoła Zawodowa im. A. Silesiusa.

Slenczek, M. (1996). Miasto Wrocław jako ośrodek przemysłowy. Prace Instytutu Geograficznego. Seria B. Geografia Społeczna i Ekonomiczna, 14, 85-91.

Wrocław w liczbach (2017). Wrocław: Urząd Statystyczny we Wrocławiu.

Dominik Sikorski, dr, adiunkt w Zakładzie Geografii Społeczno-Ekonomicznej, Instytut Geografii i Rozwoju Regionalnego, Uniwersytet Wrocławski. Jego zainteresowania badawcze koncentrują się wokół procesów przeobrażeń terenów przemysłowych w miastach, ze szczególnym uwzględnieniem ich przemian funkcjonalnych. Ponadto prowadzi badania w zakresie geografii: społecznej (ngo, alokacji 1\%), miast (badania morfologiczne) i historycznej. Jest autorem blisko 30 prac naukowych.

Dominik Sikorski, PhD, an assistant professor in the Department of Socio-Economic Geography at the Institute of Geography and Regional Development, University of Wroclaw. His research interests are focused on transformation processes of industrial areas in the cities, especially their functional changes. In addition, he conducts research in the field of social geography (NGO, 1\% allocation), cities (morphological research) and historical geography. He is the author of nearly 30 research papers.

ORCID: 0000-0003-2612-3490

Adres/address:

Uniwersytet Wrocławski Instytut Geografii i Rozwoju Regionalnego Zakład Geografii Społeczno-Ekonomicznej pl. Uniwersytecki 1, 50-137 Wrocław, Polska e-mail: dominik.sikorski@uwr.edu.pl 